\title{
Disaggregation of daily rainfall data for the Caraguatatuba city, in São Paulo State, Brazil
}

\section{Desagregação de chuvas diárias para a cidade de Caraguatatuba, no estado de São Paulo, Brasil}

\author{
Daniela Martins ${ }^{1 *}$ (D), Maria Luiza Teofilo Gandini² (D, Nadiane Smaha Kruk ${ }^{1}$ (D) and Paulo Ivo Braga Queiroz \\ ${ }^{1}$ Instituto Tecnológico de Aeronáutica, São José dos Campos, SP, Brasil \\ ${ }^{2}$ Universidade Federal de Ouro Preto, MG, Brasil \\ E-mails: engdanimartins@gmail.com (DM),mltgandini@gmail.com (MLTG), nadiane@kruk.eng.br (NSK), pi@ita.br (PIBQ)
}

Received: June 14, 2018 - Revised: July 22, 2019 - Accept: October 03, 2019

\begin{abstract}
The objective of this study is to present disaggregation coefficients for intense daily rainfalls for E2-046 rainfall station, located at Caraguatatuba, São Paulo state. The data obtained through rain gauge refer to a continuous period (31 years of series) and had a strong correlation with the measurements of the rain gauge, validating the pluviographs reading, which attributed greater reliability to the results. The average coefficient " 24 hours"/“ 1 -day" found for the study region was 1.075 , which differs significantly from the values found in literature. The relative deviation considering other durations, and consequently other precipitation coefficients in relation to the mean values of the disaggregation values of the E2-046 station reached $22.06 \%$ (18 hours/“24 hours"). The relative deviation of rainfall disaggregation coefficients of the station studied in relation to the mean coefficients for the cities of São Paulo State to small durations was quite high, reaching almost 50\% (10 minutes / "24 hours"). This reinforces the need of using local disaggregation coefficients.
\end{abstract}

Keywords: Disaggregation; Intense rainfall; Rain gauge; Caraguatatuba.

\section{RESUMO}

O objetivo deste trabalho é apresentar coeficientes de desagregação para chuvas intensas diárias do posto E2-046, situado em Caraguatatuba - SP. Os dados obtidos por meio do pluviógrafo se referem a um período contínuo (31 anos de série) e possuem forte correlação com as leituras do pluviômetro, validando as leituras do pluviógrafo, o que atribuiu maior confiabilidade aos resultados. O coeficiente médio " 24 horas"/ "1 dia" encontrado para a região de estudo foi 1,075, o qual difere dos valores encontrados na literatura. O desvio relativo considerando outras durações, e consequentemente outros coeficientes de precipitação, em relação à média da literatura chegou a 22,06\% (18 horas/“24 horas"). O desvio relativo de coeficientes de desagregação para pequenas durações do posto estudado em relação à média de coeficientes para as cidades do Estado de São Paulo foi bastante elevado, atingindo quase 50\% (10 minutos/“24 horas”). Tais desvios reforçam a necessidade de utilização de coeficientes de desagregação locais.

Palavras-chave: Desagregação; Chuvas intensas; Pluviógrafo; Caraguatatuba. 


\section{INTRODUCTION}

The knowledge of characteristics of the maximum rainfalls is fundamental to design hydraulic projects and the management of the water resources in engineering. In complex projects such as spillways, dams and bridges, estimation of the floods that may occur as well as their frequency assists and provides guidelines to design hydraulic structures.

Hydrological data of several basins do not always exist or, if they exist, they are not always available. Rainwater monitoring networks may not have pluviograph coupled to rain gauges, which prevents recording of rainfall data.

In this study, the maximum rainfall recorded during a 24 hours interval, starting at any time, will be defined as maximum rainfall " 24 hours". It shall not be confused with "1-day" rainfall that refers to the maximum rainfall observed in 1-day, always collected at the same time, considered here from 7 a.m. to 7 a.m. of the following day.

In this case, methods of daily rainfalls disaggregation into " 24 hours" rainfalls or other rainfalls with shorter durations are used, allowing to obtain specific rainfall intensities. With the breakdown of the rainy season, it is also possible to generate curves of intensity-duration-frequency (IDF) from daily rainfall data provided by rain gauges.

Pfafstetter (1957) was the pioneer in Brazil establishing these correlations and for durations shorter than one day. However, 3 of the 98 stations investigated by that author, have less than five years of observation of rain gauges, and 89 stations did not reach 30 years of data. Reduced observation periods are prone to criticism because short historical series are subject to statistical fluctuations, which can result in "false" maxima rainfall. According to Genovez and Zuffo (2000), in the second edition of Pfafstetter's work (Pfafstetter, 1982), 25 years later, there was no change in the data. For this reason, these authors recommend the use of the referred work only when one doesn't have more adequate data.

There are several other published works about rainfall disaggregation coefficients: Occhipinti and Santos (1966) developed such coefficients for São Paulo city, while Taborga (1974) and CETESB (1986) generalized it throughout Brazil; Cardoso et al. (1998) developed the same work specifically for Santa Catarina, while Genovez and Zuffo (2000) have done it for some cities in São Paulo State. Silveira (2000) did the same for the Rio Grande do Sul, while Back (2009) and Back et al. (2012), do it for Santa Catarina.

In Brazil, there is a tendency to a generalization of these coefficients of disaggregation of rainfall (OCCHIPINTI; SANTOS, 1966; TABORGA, 1974). However, Bell (1969), conducted a study about correlations in the United States which concluded that there are geographical systematic variations of these coefficients; uncertainty about this generalization comes from convective rains that are responsible for short and strong rainfall intensities. Therefore, CETESB (1986) stresses that generalization of disaggregation coefficient of rainfall from "1-day" to " 24 hours" should be viewed with reservation, since unfortunately there wasn't in Brazil research of the same nature that produced these figures in the United States. Another point highlighted by Genovez and Zuffo (2000) is that the disaggregation coefficients presented are based on very short periods to be admitted as representative for the whole country. Back et al. (2012) complement that national average values should be revised for those of regional averages, contemplating, therefore, the predominant precipitations in each region.
Furthermore, Genovez and Zuffo (2000) warn that the use of different coefficients for transforming daily rainfall into "24 hours" rainfall, even if they are close, introduce differences between the methods of determination of IDF curves.

Bell (1969) adds that the correlations do not vary significantly in relation to the return period, i.e. they are independent of frequency. However, the same author made comparisons between data from Australia, the United States, and Russia and concluded that geographical systematic patterns certainly occur and are unquestionable. In addition, Tucci (2009) also warns that the factor that relates the " 24 hours" and " 1 -day" durations may be lower for regions where convective precipitation are predominant. The referred author also noticed a slight tendency influence of the period of return.

Both Bell (1969) and Chen (1983) have developed similar techniques, using different forms of relationship time-duration and frequency for any place in the United States.

Genovez and Zuffo (2000) complement Bell (1969) and conclude that empirical disaggregation coefficients do not replace rain gauge information of any site in study, but may assist with a reasonable estimate for regions where pluviographs data are scarce and only pluviometer(s) data are available.

Recently, Teodoro et al. (2014) developed intense rainfall equations for the municipality of Aquidauana / MS by using three different methodologies of daily rainfall disaggregation (CETESB, 1986; SILVEIRA, 2000; BACK et al., 2012). It was found that the coefficients of disaggregation of daily rainfall influence considerably the determination of parameters of the IDF equation. Silva Neto et al. (2017) determined a constant of disaggregation of intense rainfalls for Tocantins State and proceeded the comparison of these constants with those obtained for other regions of Brazil. The comparison between results and the studies developed for other Brazilian regions showed variations up to $-62.30 \%$, leading to the conclusion that the use of local constants is important in the process of rainfalls disaggregation.

Abreu (2018) evaluated the assumptions of the Rainfall Relation Method of Different Durations (RRDD), analyzing pluviograph and pluviometry data and rainfall stations distributed in Minas Gerais state. The author concluded that in $93 \%$ of the cases there was no trend of the disaggregation coefficients as a function of the return period and that the analysis with local coefficients tended to increase the effectiveness of the RRDD method, providing smaller errors and better fitting statistics.

This work aims to present disaggregation coefficients for maximum daily rainfall of E2-046 rain gauge station, located in Caraguatatuba, on the north coast of São Paulo state. The specific coefficients from this station are compared to those presented in the literature in several papers published in Brazil. By means of pluviographic data, disaggregation rainfall coefficients were obtained for less than one-day duration for the climatic reality of this region.

The section "Study Area" introduces the study area and the sub-basin. The section "Materials e Method" presents the data obtained by the pluviograph and the calculation methodology. The section "Results and discussion" presents the daily disaggregation coefficient for any duration and return period, compared with values already published in the literature. In the "Conclusion", an overview of the authors and suggestions for future work are presented. 


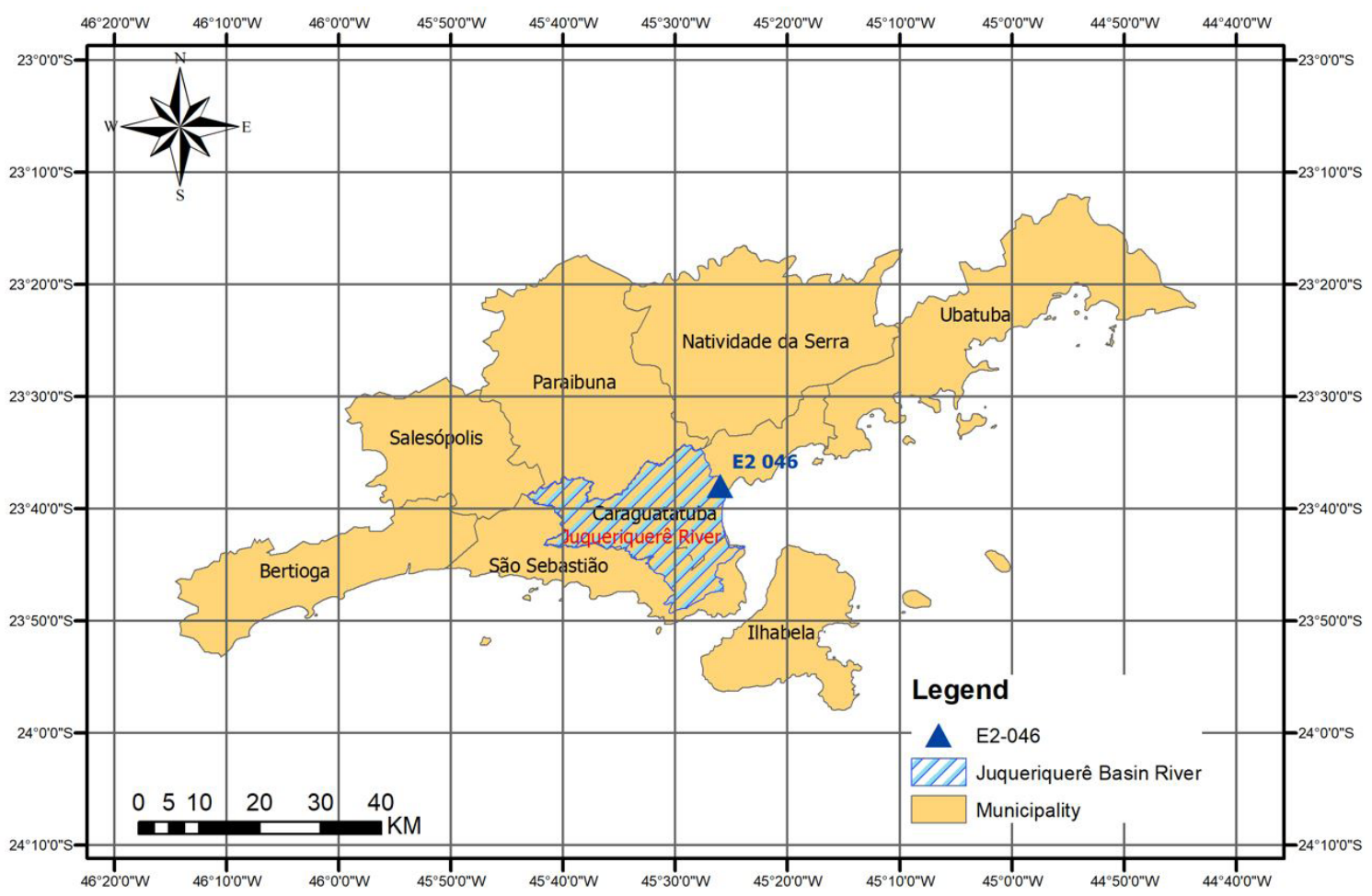

Figure 1. Location of Juqueriquerê River basin and location of the E2-046 rain gauge station of DAEE/SP.

\section{STUDY AREA: JUQUERIQUERÊ RIVER BASIN}

The region of study is the northern coast of São Paulo state, more specifically the Juqueriquerê River basin (Figure 1), which has a drainage area of $419.36 \mathrm{~km}^{2}$. This river basin belongs to subbasin no. 34 of North Coast River Basin, UGRHI-5 (Unidade de Gerenciamento de Recursos Hídricos or Water Resources Management Unit) being the largest subbasin in terms of territorial area.

Caraguatatuba city has been suffering from constant floods over the years. The region is highlighted by the growing development due to recent construction works, like the new Port of São Sebastião and the duplication of the Tamoios Highway.

\section{MATERIALS E METHODS}

\section{Rainfall data derived from E2-046 rain gauge station}

The rainfall data derived from E2-046 rain gauge station were recorded by a mechanical pluviograph. Throughout the 31-year period (1971 to 2001), 545 heavy rainfalls were read (Table 1), and they were considered as the major rainfalls, which means, total precipitates above $20 \mathrm{~mm}$. Rainfall totals less than $20 \mathrm{~mm}$ were neglected for reading heavy rainfalls. Through reading these 545 rainfalls, it was possible to obtain the intensity for each duration during the 31 years of data. Some rainfalls had a short duration, like 20 minutes and others lasted 8,010 minutes, that is, almost 6 days. The " 24 hours" rainfall of the rain gauge is obtained through the maximum intensity for a duration of 1440 minutes.

Rainfall recorded by the rain gauge (located at the same station E2-046) is done at $7 \mathrm{~h}$. In this case, it is only possible to get the total daily precipitation, which is from $7 \mathrm{a} . \mathrm{m}$. to $7 \mathrm{a} . \mathrm{m}$. on the following day.
DAEE/SP (Department of Water and Electric Energy) made available the data, which were manually read and processed by the Data Processing Company of São Paulo State (Prodesp).

Furthermore, the moving averages were worked in computational algorithm to generate the maximum intensities in $10,20,30,60,120,180,360,720,1080$ and 1440 minutes in duration, for all recorded rainfalls.

\section{Correlation between rainfalls of different durations}

The magnitude of a hydrological event can be represented as the mean added to the product of the standard deviation with the frequency factor (KITE, 1977; MAYS, 2010). Chow (1964) proposed the following equation:

$X_{T}=\bar{x}+K_{T} S_{x}$

where is the average of the annual maximum values, frequency factor that varies with the number of years of sample data and the period of return and is the standard deviation of the sample.

After calculating the magnitude of the intensities (equation 1) of all the rainfalls, it was possible to calculate the coefficient of disaggregation of rainfall, which is defined by:

$C=\frac{X_{T(" 24 \text { horas" })}}{X_{T(" 1 \text { dia" })}}=\frac{i_{24 h} \cdot d}{P_{\text {max }}}$

where is the relation " 24 hours"/" 1 -day", the maximum annual intensity recorded by the pluviograph $(\mathrm{mm} / \mathrm{min})$, is the duration of the rainfall (in min) and (in $\mathrm{mm}$ ) is the annual maximum daily rainfall recorded by the rain gauge. 
After the correlation between the daily rainfalls and the "24 hours" rainfalls was obtained, disaggregation was carried with the 545 rainfalls derived from the E2-046 rain gauge station. The correlations were made from rainfall ratios of 10, 20, 30, 60, $120,180,360,720$ and 1080 minutes with respective rainfalls of "24 hours". These are the standard durations for IDF generation (CETESB, 1986). Otherwise, Pfafstetter (1957) established these durations in such a way that a geometric progression of ratio 2 was formed in order to allow a curve to easily join the results in logarithmic scale. These correlations allow determining rainfall intensities with durations of less than "1-day", that is, from daily data obtained from a rain gauge.

The ratios were calculated according to the equation 3 :

$R\left(x_{\min } / y_{\min }\right)=\frac{X_{T}\left(d_{x}\right)}{X_{T}\left(d_{y}\right)}$

where $R\left(x_{\min } / y_{\min }\right)$ is the relationship between rainfalls with two specific durations, is the magnitude of rainfall intensities recorded by the pluviograph for any duration of and .

The data from rain gauge station E2-046 were submitted to the Kolmogorov-Smirnov goodness of fit test, as modified by Lilliefors as presented Martins (2018).

Table 1. Number of annual heavy daily rainfall recorded in the period 1971 to 2001 for E2-046 rain gauge station.

\begin{tabular}{|c|c|}
\hline Years & Number of rainfall records \\
\hline 1971 & 1 \\
\hline 1972 & 2 \\
\hline 1973 & 2 \\
\hline 1974 & 14 \\
\hline 1975 & 23 \\
\hline 1976 & 30 \\
\hline 1977 & 6 \\
\hline 1978 & 16 \\
\hline 1979 & 16 \\
\hline 1980 & 27 \\
\hline 1981 & 14 \\
\hline 1982 & 19 \\
\hline 1983 & 30 \\
\hline 1984 & 15 \\
\hline 1985 & 22 \\
\hline 1986 & 30 \\
\hline 1987 & 22 \\
\hline 1988 & 27 \\
\hline 1989 & 18 \\
\hline 1990 & 21 \\
\hline 1991 & 16 \\
\hline 1992 & 22 \\
\hline 1993 & 13 \\
\hline 1994 & 18 \\
\hline 1995 & 22 \\
\hline 1996 & 18 \\
\hline 1997 & 15 \\
\hline 1998 & 28 \\
\hline 1999 & 14 \\
\hline 2000 & 11 \\
\hline 2001 & 13 \\
\hline Total & 545 \\
\hline
\end{tabular}

Martins et al. (2017a).

\section{RESULTS E DISCUSSION}

Initially, the relation between the maximum annual rainfall of " 24 hours" recorded in the pluviometer and the maximum annual rainfall of one day, recorded in the rain gauge.

The data presented here are analyzed according to the distribution model of Gumbel-Chow extreme values (Chow, 1964).

Table 2 shows the calculation of the rainfall disaggregation coefficient obtained by equation 1 and 2 .

According to Genovez and Zuffo (2000), the value of the ratio precipitations " 24 hours" / "1-day" should always be greater than or equal to 1.0. If the values are lower than 1.0 then the data series should be reviewed.

In 6 of the 31 years of rainfall data (Table 2), the daily maximums exceeded those of " 24 hours". The rain gauge and pluviometer are in the same station, although they are different equipment. Therefore, some real conditions may result in small variations between the two measures. As an example, the reading time of the rain gauge may not be accurate, resulting in a rainfall lasting more than 24 hours being counted as daily rainfall. Eventually, the rain gauge may lock during siphoning and may not register a whole rainfall somehow. Facts like this can cause dispersion and difference between rain gauge and pluviograph

Table 2. Maximum daily values obtained by pluviometer and from rain gauge station E2-046 in the period 1971 to 2001.

\begin{tabular}{|c|c|c|c|}
\hline Years & "24 hours" & "1-day" & "24 hours"/ "1-day" \\
\hline 1971 & 171.4 & 183.8 & 0.932 \\
\hline 1972 & 96.5 & 90.5 & 1.066 \\
\hline 1973 & 135.4 & 92.3 & 1.467 \\
\hline 1974 & 141.1 & 129.0 & 1.094 \\
\hline 1975 & 148.3 & 144.9 & 1.024 \\
\hline 1976 & 265.0 & 224.6 & 1.180 \\
\hline 1977 & 38.9 & 42.8 & 0.908 \\
\hline 1978 & 154.1 & 139.6 & 1.104 \\
\hline 1979 & 122.0 & 70.6 & 1.729 \\
\hline 1980 & 82.1 & 33.3 & 2.465 \\
\hline 1981 & 169.9 & 155.9 & 1.090 \\
\hline 1982 & 99.4 & 96.5 & 1.030 \\
\hline 1983 & 102.2 & 75.5 & 1.354 \\
\hline 1984 & 67.0 & 61.8 & 1.083 \\
\hline 1985 & 125.3 & 109.4 & 1.145 \\
\hline 1986 & 89.3 & 67.3 & 1.327 \\
\hline 1987 & 66.2 & 55.9 & 1.185 \\
\hline 1988 & 79.2 & 58.8 & 1.347 \\
\hline 1989 & 96.5 & 80.9 & 1.193 \\
\hline 1990 & 123.8 & 120.7 & 1.026 \\
\hline 1991 & 79.2 & 56.2 & 1.409 \\
\hline 1992 & 118.1 & 120.2 & 0.982 \\
\hline 1993 & 172.8 & 100.0 & 1.728 \\
\hline 1994 & 121.0 & 127.3 & 0.950 \\
\hline 1995 & 90.7 & 91.0 & 0.997 \\
\hline 1996 & 141.1 & 140.6 & 1.004 \\
\hline 1997 & 99.4 & 98.2 & 1.012 \\
\hline 1998 & 95.0 & 69.8 & 1.362 \\
\hline 1999 & 90.7 & 70.2 & 1.292 \\
\hline 2000 & 116.6 & 99.8 & 1.169 \\
\hline 2001 & 49.7 & 51.5 & 0.965 \\
\hline
\end{tabular}


records. Hence, the methodology of using both pluviograph and rain gauge data may eventually cause a random dispersion of the "24 hours/1-day" column, which results in some values smaller than unity that would not take place if rain gauge data were used in daily rain estimation. Despite this fact, the choice of this methodology is justified by consistency with long-standing references on the subject (e.g., OCCHIPINTI; SANTOS, 1966). It is understood that this dispersion is not biased and the six results of " 24 hours/1-day" smaller than unity must not be discarded due to the risk of bias generation, that is, an artificial rise of the "24 hours/1-day" average value.

Table 3 presents a comparison between several disaggregation coefficients obtained in literature and the average coefficient obtained in the present work. According to Magni (1984), these correlations are constant disregarding the return period. By applying the Gumbel-Chow disaggregation methodology, a variation in the return period is experienced, which contradicts other authors. The average value (calculated between $T_{r}=2$ and $\left.T_{r}=100\right)$ is presented in Table 4.

This work determined an average value for comparison with literature and values which vary according to the return period, which was established by Gumbel-Chow theory (Chow, 1964).

Disaggregation coefficients were calculated according to Table 4 in order to convert " 1 -day" rainfall obtained by pluviometer to "24 hours" rainfall (in the absence of a rain gauge). The "1-day" rainfall should be multiplied by the according to return period which is design-specified according to Table 4 and may vary from 1.114 for $T_{r}=2$ a 1.058 for $T_{r}=100$.

Table 5 presents also the relationship between pluviometric height calculated for E2-046 rain gauge station and values found in the literature. The average and standard deviation of the ratio between these values were calculated and the standard deviation didn't surpass $5.53 \%$. Despite these small deviations, disaggregation may introduce more or less conservative results depending on the hydraulic design to which calculation is intended.

According to the discussion posted in the introductory section, it is important to obtain regional coefficients, like the ones obtained in the present work for Caraguatatuba County at São Paulo State. The relative errors (presented in Table 5) in relation to average disaggregation values for E2-046 rain gauge station reached to $20.44 \%$.

Table 6 presents disaggregation values for all duration values in relation to " 24 hours" rainfall according to Equation 3. Therefore, it is possible to fit a curve which allows calculating rainfall intensities to any duration. These values can be obtained by using the disaggregation curve for E2-046 rain gauge station presented in Equation below,

Table 3. Coefficients " 24 hours"/"1-day" found in the literature.

\begin{tabular}{|c|c|c|}
\hline Source & $\mathbf{C}$ & Location \\
\hline U. S. Weather Bureau (1962) & 1.130 & Haway \\
\hline Weiss (1964) & 1.14 & United States \\
\hline Occhipinti and Santos (1966) & 1.136 & São Paulo county* \\
\hline Taborga (1974) & 1.095 & Brazil \\
\hline Magni (1984) & 1.040 (0.961(24hours/1day)) & São Paulo county ${ }^{* *}$ \\
\hline Genovez e Pegoraro (1998) apud Genovez and Zuffo (2000) & 1.110 (average value) & São Paulo state \\
\hline Back et al. (2012) & 1.170 & Santa Catarina \\
\hline Present work & 1.075 (average value) & Caraguatatuba \\
\hline
\end{tabular}

$* 36$ years of historical data and $* * 49$ years of historical data.

Table 4. Coefficients "24 hours"/"1-day" obtained by Gumbel-Chow (Chow, 1964).

\begin{tabular}{ccccccccc}
\hline Tr & $\mathbf{2}$ & $\mathbf{5}$ & $\mathbf{1 0}$ & $\mathbf{1 5}$ & $\mathbf{2 0}$ & $\mathbf{2 5}$ & $\mathbf{5 0}$ & $\mathbf{1 0 0}$ \\
\hline $\mathrm{C}$ & 1.114 & 1.085 & 1.075 & 1.071 & 1.068 & 1.066 & 1.062 & 1.058 \\
\hline
\end{tabular}

$\mathrm{C}$ (average value) $=1.075$.

Table 5. Coefficients "24 hours"/ "1-day" derived from E2-046 rain gauge station compared with some values obtained in the literature.

\begin{tabular}{|c|c|c|c|c|c|c|c|c|c|c|}
\hline & $\frac{10 \min }{30 \min }$ & $\frac{20 \min }{30 \min }$ & $\frac{30 \mathrm{~min}}{60 \mathrm{~min}}$ & $\frac{60 \min }{1440 \min }$ & $\frac{120 \min }{1440 \min }$ & $\frac{180 \min }{1440 \min }$ & $\frac{360 \min }{1440 \min }$ & $\frac{720 \min }{1440 \min }$ & $\frac{1080 \min }{1440 \min }$ & $\frac{1440 \min }{" 1 \text { day" }}$ \\
\hline $\begin{array}{l}\text { Caraguatatuba } \\
\text { Average }\end{array}$ & 0.448 & 0.759 & 0.685 & 0.390 & 0.522 & 0.596 & 0.714 & 0.843 & 0.920 & 1.075 \\
\hline $\begin{array}{l}\text { Occhipinti and } \\
\text { Santos (1966) }\end{array}$ & 0.54 & 0.81 & 0.74 & 0.42 & - & - & 0.72 & 0.85 & - & 1.14 \\
\hline Magni (1984) & 0.51 & 0.8 & 0.74 & 0.51 & - & - & 0.78 & 0.88 & - & - \\
\hline $\begin{array}{l}\text { U.S. Weather } \\
\text { Bureau (1962) }\end{array}$ & 0.57 & - & 0.79 & - & - & - & - & - & - & 1.13 \\
\hline Denver & 0.63 & 0.84 & - & - & - & - & - & - & - & - \\
\hline Average & 0.563 & 0.817 & 0.757 & 0.465 & & & 0.750 & 0.865 & & 1.135 \\
\hline Deviation (\%) & 5.75 & 2.90 & 3.56 & 3.73 & & & 1.81 & 1.11 & & 3.01 \\
\hline Relative error $(\%)$ & -20.44 & -0.71 & -9.41 & -16.03 & & & -4.82 & -2.56 & & -5.30 \\
\hline
\end{tabular}


$c=0,001606 \ln ^{4}(d)+0,032339 \ln ^{3}(d)-$

$0,23853 \ln ^{2}(d)-0,58198 \ln (d)+0,54489$,

where $d(\mathrm{~min})$ is a duration to which the correlation is desired and the dimensionless $c$ is the correlation obtained for the chosen duration.

Table 6 presents disaggregation values for the durations commonly used in drainage design. In fact, average values that don't match with the reality of any catchment basin may lead to wrong calculation of any basin exutory flow, leading to wrong hydraulic design.

Figure 2 illustrates the graphed values of average correlations obtained from Table 6. The Equation 4 was used to adjust a curve to data series of Caraguatatuba. Such adjustment was performed with $\mathrm{R}^{2}=0.99$.

This curve represents the adjustment of the average values provided by Table 5, where they were generated by Equation 4 for the selected durations: 10, 20, 30, 60,120,180,360, 720 and 1080 minutes of the data source derived from the E2-046 rain gauge.

Silveira (2000) already discussed about the difficulty of obtaining rainfall values for intermediate duration, as disaggregation coefficients available in the Brazilian literature are usually presented tabular form.
In Table 7, a comparison was made of disaggregation coefficients for some cities of São Paulo state defined by basic guidelines of the urban drainage design of São Paulo County (FCTH, 1999). Unfortunately the size and availability period of the data was not detailed and this information can vary greatly the correlations, as the case of E3-149 rain gauge station, that the authors comment on just that the values are widely varied. A extend and reliable historical data series are believed to produce better correlations.

For short durations, the deviation in relation to the average of other cities exceeds 100\%, decreasing, however, with the raising of the duration. In other words, the establishing of average rainfall coefficients for short durations may cause completely wrong intensities.

We believe that for shorts return periods, that is to say, shorter than 15 years, it is recommended the adoption of average disaggregation, according to Table 6 , because the values would be insecure safety to micro drainage design. Already for return periods greater than 15 years, it is strongly recommended the rainfall disaggregation should follow the Gumbel-Chow methodology presented in this work.

Table 6. Rainfall disaggregation obtained to E2-046 rain gauge station.

\begin{tabular}{|c|c|c|c|c|c|c|c|c|c|}
\hline $\operatorname{Tr}$ (years) & $\frac{10 \min }{1440 \mathrm{~min}}$ & $\frac{20 \mathrm{~min}}{1440 \mathrm{~min}}$ & $\frac{30 \mathrm{~min}}{1440 \mathrm{~min}}$ & $\frac{60 \mathrm{~min}}{1440 \mathrm{~min}}$ & $\frac{120 \min }{1440 \min }$ & $\frac{180 \min }{1440 \min }$ & $\frac{360 \mathrm{~min}}{1440 \mathrm{~min}}$ & $\frac{720 \min }{1440 \min }$ & $\frac{1080 \mathrm{~min}}{1440 \mathrm{~min}}$ \\
\hline 2 & 0.111 & 0.188 & 0.242 & 0.340 & 0.449 & 0.520 & 0.652 & 0.804 & 0.905 \\
\hline 10 & 0.120 & 0.203 & 0.268 & 0.392 & 0.524 & 0.599 & 0.716 & 0.844 & 0.920 \\
\hline 15 & 0.121 & 0.205 & 0.271 & 0.397 & 0.531 & 0.606 & 0.721 & 0.848 & 0.922 \\
\hline 20 & 0.121 & 0.205 & 0.272 & 0.399 & 0.535 & 0.610 & 0.725 & 0.850 & 0.922 \\
\hline 25 & 0.121 & 0.206 & 0.273 & 0.401 & 0.538 & 0.613 & 0.727 & 0.851 & 0.923 \\
\hline 50 & 0.122 & 0.207 & 0.275 & 0.406 & 0.545 & 0.620 & 0.733 & 0.855 & 0.924 \\
\hline 100 & 0.123 & 0.208 & 0.277 & 0.409 & 0.550 & 0.625 & 0.737 & 0.857 & 0.925 \\
\hline Average & 0.120 & 0.203 & 0.267 & 0.390 & 0.522 & 0.596 & 0.714 & 0.843 & 0.920 \\
\hline
\end{tabular}

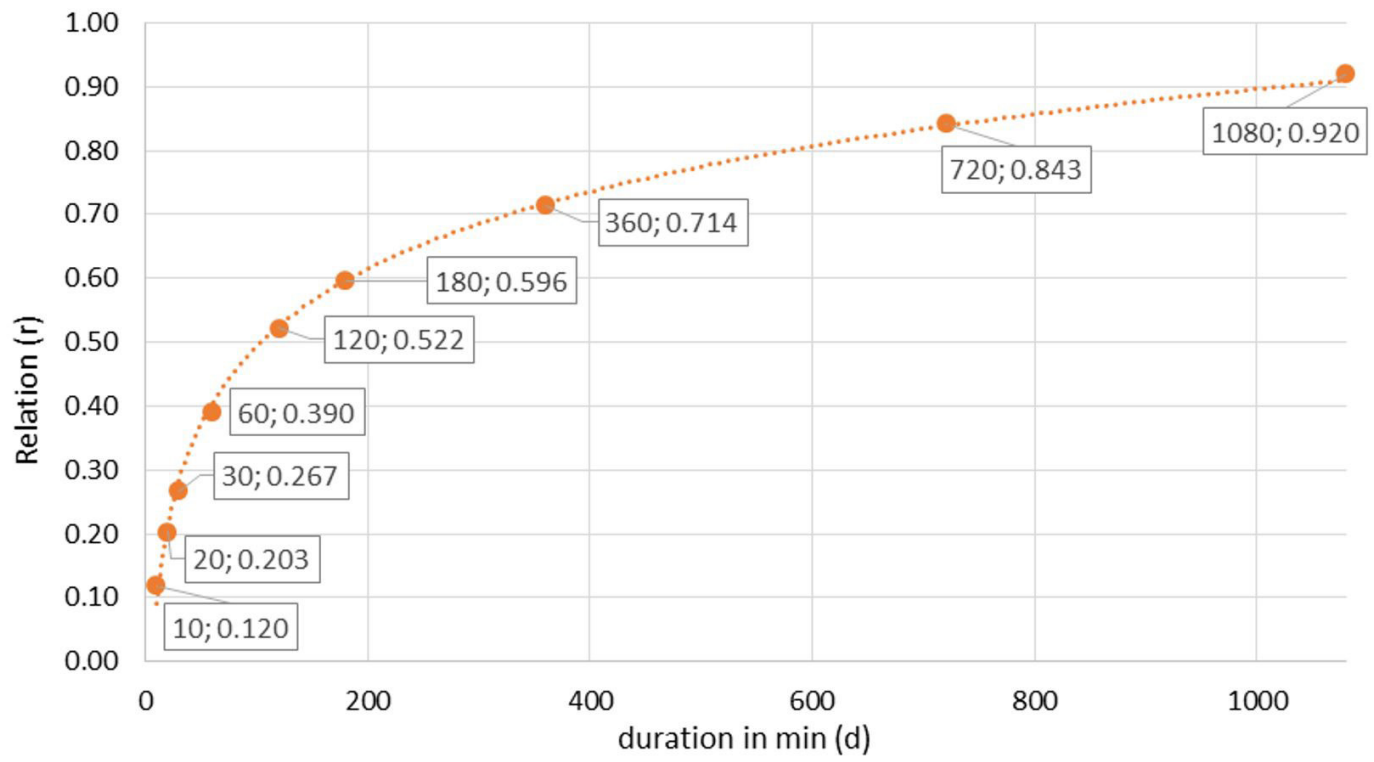

Figure 2. Correlation of observed durations at E2-046 rain gauge between the years 1971 and 2001. 
Table 7. Comparison of the disaggregation between coefficients obtained from E2-046 rain gauge station and coefficients of Alto do Tietê (FCTH, 1999).

\begin{tabular}{|c|c|c|c|c|c|c|c|c|c|c|}
\hline \multicolumn{11}{|c|}{ Rainfall disaggregation coefficients of " 24 hours" (dimensionless) } \\
\hline \multirow{2}{*}{ Prefix } & \multirow{2}{*}{ Location } & \multicolumn{9}{|c|}{ Duration (min) } \\
\hline & & 10 & 20 & 30 & 60 & 120 & 180 & 360 & 720 & 1080 \\
\hline E3-032 & Mogi das Cruzes & 0.218 & 0.308 & 0.354 & 0.434 & 0.526 & 0.585 & 0.701 & 0.838 & 0.929 \\
\hline E3-034 & Cotia & 0.237 & 0.328 & 0.375 & 0.456 & 0.544 & 0.603 & 0.715 & 0.845 & 0.932 \\
\hline E3-047 & Franco da Rocha & 0.186 & 0.271 & 0.316 & 0.398 & 0.491 & 0.553 & 0.675 & 0.822 & 0.922 \\
\hline E3-068 & Itapecerica & 0.243 & 0.334 & 0.380 & 0.461 & 0.550 & 0.608 & 0.719 & 0.847 & 0.933 \\
\hline E3-148 & Mauá & 0.247 & 0.339 & 0.386 & 0.465 & 0.554 & 0.612 & 0.722 & 0.849 & 0.935 \\
\hline E3-149 & Santo André & 0.099 & 0.167 & 0.206 & 0.282 & 0.376 & 0.443 & 0.583 & 0.764 & 0.894 \\
\hline E3-150 & Rudge Ramos & 0.230 & 0.319 & 0.365 & 0.447 & 0.536 & 0.594 & 0.708 & 0.842 & 0.931 \\
\hline E3-142 & S. B. Campo & 0.179 & 0.264 & 0.309 & 0.390 & 0.483 & 0.546 & 0.669 & 0.818 & 0.920 \\
\hline E3-085 & S. C. do Sul & 0.245 & 0.335 & 0.382 & 0.463 & 0.552 & 0.609 & 0.719 & 0.848 & 0.934 \\
\hline E3-251 & USP & 0.262 & 0.353 & 0.400 & 0.480 & 0.568 & 0.624 & 0.731 & 0.856 & 0.937 \\
\hline E3-096 & Ponte Pequena & 0.248 & 0.339 & 0.385 & 0.466 & 0.554 & 0.612 & 0.721 & 0.850 & 0.935 \\
\hline E3-035 & IAG & 0.234 & 0.323 & 0.370 & 0.450 & 0.540 & 0.599 & 0.711 & 0.844 & 0.932 \\
\hline E3-052 & Congonhas & 0.268 & 0.360 & 0.407 & 0.486 & 0.573 & 0.629 & 0.735 & 0.858 & 0.938 \\
\hline E3-007 & M. Santana & 0.279 & 0.372 & 0.418 & 0.497 & 0.583 & 0.638 & 0.742 & 0.862 & 0.940 \\
\hline Average & & 0.240 & 0.331 & 0.378 & 0.459 & 0.547 & 0.606 & 0.717 & 0.846 & 0.933 \\
\hline E2-046 & $\begin{array}{l}\text { Caraguatatuba } \\
\text { (average value) }\end{array}$ & 0.120 & 0.203 & 0.267 & 0.390 & 0.522 & 0.596 & 0.714 & 0.843 & 0.920 \\
\hline \multicolumn{2}{|c|}{ Average rate $(\%)$} & 100.62 & 63.21 & 41.16 & 17.42 & 4.71 & 1.53 & 0.44 & 0.37 & 1.37 \\
\hline
\end{tabular}

\section{CONCLUSIONS}

The proposal of presenting disaggregation coefficients for rainfall is important for the development of IDF curves for any region in study. Although some authors have established disaggregation coefficients for the whole country, it is understood that these figures unduly disseminated are prone to large variations in their rainfall estimates. This usually happens due to the physical characteristics of convective rains, which cause rainfall events of high intensity and short duration all over the world. Rainfall events of short duration take place frequently under convection phenomenon, while longer duration events may have a combined orographic and frontal effects.

Rain gauge data present a strong correspondence with pluviometer data of E2-046 rainfall station, which validates the recently obtained pluviograph readings and assigns more reliability to the results obtained herein. Data obtained from pluviograph refer to an uninterrupted period (a 31-year series), which, according to WMO, is enough to establish a climatological normal.

It was also concluded that the relative deviation of disaggregation coefficient for short duration of the rainfall station studied in relation to the average coefficients of São Paulo state was very high, reaching 50\% (10 minutes / "24 hours"). This may cause large variations in micro drainage design for small catchments, where the time of concentration is short.

The employment of these coefficients in the region studied or even in other climatically similar regions is of great value for hydraulic engineering projects. It is noticed that this work data allowed obtaining disaggregation coefficients dependent of the return period; nevertheless, it is recommended for hydraulic works with large return periods prescribed by standard (over 100 years) to adopt the Gumbel-Chow method for disaggregation of the design rainfall.
As a suggestion for future works, it would be recommended more deep investigation of new disaggregation coefficients in the scenario of climate changes. Martins et al. (2017b) e Martins (2018) performed statistical analyses of daily maxima data obtained by the E2-046 rain gauge, which included a non-parametric test of stationarity (Mann-Kendall). These analyses indicated with a high level of significance that de stationarity hypothesis should be rejected.

\section{ACKNOWLEDGEMENTS}

The authors are indebted to the São Paulo State Department of Water and Electrical Energy (Departamento de Águas e Energia Elétrica do Estado de São Paulo - DAEE/SP) in the person of Eng. Nelson Magni for the rainfall data supplied. The authors are also indebted to Eng. Nelson not only for his confidence and for providing reading instructions, but also for his engagement in data post-processing and generation of intense rainfall data.

\section{REFERENCES}

ABREU, M. C. Desempenho de métodos de desagregação de chuvas intensas. 2018. 123 f. Tese (Doutorado do Programa de Pós-Graduação em Meteorologia Aplicada) - Universidade Federal de Viçosa, Viçosa, 2018.

BACK, A. J. Relações entre precipitação intensas de diferentes durações ocorridas no município de Urussanga, SC. Revista Brasileira de Engenharia Agrícola e Ambiental, v. 13, n. 2, p. 170-175, 2009. http://dx.doi.org/10.1590/S1415-43662009000200010.

BACK, A. J.; OLIVEIRA, J. L. R.; HENN, A. Relações entre precipitações intensas de diferentes durações para desagregação 
da chuva diária em Santa Catarina. Revista Brasileira de Engenharia Agrícola e Ambiental, v. 16, n. 4, p. 391-398, 2012.

BELL, F. G. Generalized rainfall - duration - frequency relationships. Journal of the Hydraulics Division, v. 95, n. HY1, p. 311-327, 1969.

CARDOSO, C. O.; ULLMANN, M. N.; BERTOL, I. Análise de chuvas intensas a partir da desagregação das chuvas diárias de Lages e de Campos Novos (SC). Revista Brasileira de Ciência do Solo, v. 22, n. 1, p. 131-140, 1998. http://dx.doi.org/10.1590/ S0100-06831998000100018. [online]

CETESB - COMPANHIA DE TECNOLOGIA DE SANEAMENTO AMBIENTAL. Drenagem urbana: manual de projeto. São Paulo: CETESB, 1986. 476 p.

CHEN, C. Rainfall Intensity - duration - frequency formulas. Journal of Hydraulic Engineering, v. 109, n. 12, p. 21, 1983. http://dx.doi. org/10.1061/(ASCE)0733-9429(1983)109:12(1603).

CHOW, V. T. Handbook of applied hydrology. New York: McGrawHill, 1964. p. 1468.

FCTH - FUNDAÇÃO CENTRO TECNOLÓGICO DE HIDRÁULICA, PREFEITURA DO MUNICÍPIO DE SÃO PAULO. Diretrizes Básicas para projetos de Drenagem Urbana no Município de São Paulo, São Paulo: FCTH, 1999.

GENOVEZ, A. M.; ZUFFO, A. C. Chuvas Intensas no Estado de São Paulo: Estudos Existentes e Análise Comparativa. Revista Brasileira de Recursos Hídricos, v. 5, n. 3, p. 45-58, 2000. http:/ /dx.doi. org/10.21168/rbrh.v5n3.p45-58.

KITE, G. W. Frequency and risk analysis in bydrology. Fort Collins: Water Resources Publications, 1977.

MAGNI, N. L. G. Estudo pontual de chuvas intensas - proposição e análise de uma metodologia de estudo das relações intensidade duração frequência definidas para um ponto. 1984. Dissertação (Mestrado em Engenharia Civil) - Escola Politécnica da Universidade de São Paulo, São Paulo, 1984.

MARTINS, D.; KRUK, N. S.; MAGNI, N. L. G.; QUEIROZ, P. I. B. Comparação de duas metodologias de obtenção da equação de chuvas intensas para a cidade de Caraguatatuba (SP). Revista $D A E$, v. 207, n. 1, p. 34-49, 2017a.

MARTINS, D.; QUEIROZ, P. I. B.; KRUK, N. S.; GANDINI, M. L. T. Analysis of trends in extreme precipitation events in a city of Brazilian coast under climate change. In: IWA/IAHR INTERNATIONAL CONFERENCE ON URBAN DRAINAGE, 14., 2017, Praga. Proceedings... United Kingdom: IWA/IAHR, 2017b.

MARTINS, D. Impactos das projeções de mudanças climáticas no dimensionamento de sistemas de drenagem: o caso de Caraguatatuba. 2018. 190 f. Tese (Doutorado em Infra-Estrutura Aeronáutica) Instituto Tecnológico de Aeronáutica, São José dos Campos, 2018.

MAYS, L. W. Water resources engineering. 2nd ed. New Jersey: John Wiley Sons Inc., 2010. 890 p.
OCCHIPINTI, A. G., SANTOS, P. M. Relação entre as precipitações máximas de "um dia" e de "24 horas" na cidade de São Paulo. In: III SIMPÓSIO DE REDES HIDROLÓGICAS, 1., 1966, Belo Horizonte. Anais... São Paulo: IAG, 1966. 13 p.

PFAFSTETTER, O. Chuvas Intensas no Brasil. $1^{\text {a }}$ ed. Rio de Janeiro: DNOS, 1957. 419 p.

PFAFSTETTER, O. Chuvas Intensas no Brasil. $2^{\mathrm{a}}$ ed. Rio de Janeiro: DNOS, 1982. $426 \mathrm{p}$.

SILVA NETO, V. L.; VIOLA, M. R.; SILVA, D. D.; MELLO, C. R.; PEREIRA, S. B.; GIONGO, M. Daily rainfall disaggregation for Tocantins State. Revista Ambiente \& Água, v. 12, n. 4, p. 605-17, 2017. http://dx.doi.org/10.4136/ambi-agua.2077.

SILVEIRA, A. L. L. Equação para os coeficientes de desagregação de chuva. Revista Brasileira de Recursos Hídricos, v. 5, n. 4, p. 143-147, 2000. http://dx.doi.org/10.21168/rbrh.v5n4.p143-147.

TABORGA, J. T. Práticas Hidrológicas. Rio de Janeiro: TRANSCON Consultoria Técnica Ltda, 1974. 120 p.

TEODORO, P. E.; NEIVOCK, M. P.; MARQUES, J. R. F.; FLORES, A. M. F.; RODRIGUES, C. C. B. Influência de diferentes coeficientes de desagregação na determinação de equações IDF para Aquidauana/MS. Revista Eletrônica de Engenharia Civil, v. 9, n. 2, p. 1-9, 2014.

TUCCI, C. E. M. Hidrologia: ciência e aplicação. Porto Alegre: UFRGS/ ABRH, 2009. 943 p.

U.S. WEATHER BUREAU. Rainfall-frequency atlas of the Hawaiian Islands for areas to 200 square miles, durations to 24 hours, and return periods from l to 100 Years. Washington, D.C.: U.S. Weather Bureau, 1962. (Technical Paper, 43).

WEISS, L. L. Ratio of true to fixed-interval maximum rainfall. Journal of the Hydraulics Division, v. 90, n. 1, p. 77-82, 1964.

\section{Authors contributions}

Daniela Martins: led the design of the proposed methodology, performed the numerical calculations, and participated in the analysis and discussion of results and paper writing.

Maria Luíza Teófilo Gandini: contributed to the general idea of the research, participated in the analysis and discussion of the results.

Nadiane Smaha Kruk: contributed to the general idea of the research, participated in the analysis and discussion of the results.

Paulo Ivo Braga de Queiroz: contributed to the numerical methodology and contributed to the writing. 